\title{
Animation Media on Human Digestive System Material for Fifth-Grade Elementary School Students
}

\author{
Ni Nyoman Esti Juniarti1*, Gede Wira Bayu2 ${ }^{2}$ I Gde Wawan Sudatha ${ }^{3}$
}

1,2,3 Universitas Pendidikan Ganesha, Singaraja, Indonesia

\section{ART I C L E I N F O}

Article history:

Received March 20, 2021

Revised March 21, 2021

Accepted July 10, 2021

Available online August 25, 2021

\section{Kata Kunci}

Media Animasi, Sistem

Pencernaan Manusia

Keywords:

Animation Media, Human

Digestive System

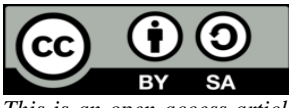

This is an open access article under the CC BY-SA license.

Copyright (C) 2021 by Author. Published by Universitas Pendidikan Ganesha.

\section{A B S T RA C T}

The lack of understanding of the learning material has an impact on the results of student learning. Teachers only depend on a single source, textbooks, so it is pretty tricky for students to learn abstract material. In addition, teachers in teaching and learning activities only use conventional methods to focus on the teacher, not the students. This study aims to develop animated video learning media on the human digestive system material for fifth-grade elementary school. Media development in research uses the ADDIE model, which includes the Analyze, Design, Development, Implementation, and Evaluation stages. The data collection method in this study used a questionnaire method and a rating scale instrument-the data analysis technique used qualitative descriptive statistical data analysis and quantitative descriptive statistics. The study result showed the calculation result of the average validity test score; the result is that the percentage obtained in terms of the material as a whole is $95.71 \%$. The percentage of learning material experts is 90-100 with outstanding qualifications and does not need to be revised. Calculating the percentage of the validity test in terms of the overall design is $94.61 \%$. The percentage of learning design experts is $90-100$ with outstanding qualifications and does not need to be revised. From the average score in terms of media experts, it was stated that the learning media had outstanding qualifications with $92.93 \%$. Meanwhile, from the practitioner test, it was stated that the learning media had outstanding qualifications with an overall percentage of $100 \%$. So, animated video learning media is feasible to use in learning. This research implies that animated video media can help students in the learning process.

\section{INTRODUCTION}

Science and technology development has consequences for every generation in several fields of Education (Saurina, 2016). Speedily developing science and technology requires the high growth of Education quality; therefore, the rate of human resources can be increased (Awalia et al., 2019; Lase, 2019; Willya et al., 2019). Through Education, individuals can develop their skills and potential (Muslina et al., 2018; Robandi \& Mudjiran, 2020). In addition, education also aims to build capable, creative, independent, and responsible human beings (Sutrisno, 2016). Quality human resources can be 
achieved through an optimal learning process (Hanik, 2020; Yulianingsih et al., 2020). The learning process can run well if it involves the students' activeness, the need, and the use of the learning media according to students' characteristics. (Crismono, 2017; Novita \& Pratama, 2019). Furthermore, learning media must also be developed with various innovations following the science and technology development (Manuaba, 2017; Kuswanto \& Walusfa, 2017; Putri, 2017).

Indeed, teachers only rely on textbooks in learning activities, so it is difficult for students to grasp the material and perform the tasks given. Furthermore, learning tends to be monotonous, making students bored (Sadikin \& Hamidah, 2020; Wahyono et al., 2020). Learning using only the teachercentered and assignment methods makes students less active in the classroom (Pertiwi et al., 2019; Widiatmika et al., 2017). The results of interviews with a Homeroom Teacher for $5^{\text {th }}$-grade students at the $2^{\text {nd }}$ Kubu Public Elementary School support this. It showed that the lack of media for school learning overwhelms teachers in finding media for learning subjects. It reduces the enthusiasm of students and makes the material difficult to understand during their online learning. Furthermore, the results of science learning remain relatively low and below the minimum learning mastery standard score. If the problem is left unchecked, an effective solution to overcome these problems is needed in the online learning process.

The solution is to use the learning media. Learning media can help students understand the material given by the teacher well (Diputra, 2016; Shetu et al., 2021; Sunismi, 2015). Therefore, learning video becomes one of the media which can help students to learn. Learning videos can help students learn materials quickly and increase students' motivation to learn (Awalia et al., 2019; Heo \& Toomey, 2020). Learning video allows students to understand abstract subjects to be more concrete, so students will not be quickly bored in the classroom (Andriyani \& Suniasih, 2021; Panjaitan, 2020; Soucy et al., 2016; Taqiya et al., 2019). Therefore, students' interest and motivation for learning can be increased. Animated video is a type of learning media that can increase the enthusiasm and motivation of students to learn. Animated media is a learning media in the video that can visualize abstract concepts to make them more real (Muslina et al., 2018; Panjaitan, 2020; Stoll et al., 2021). The development of animated videos for elementary schools based on elementary school students' characteristics, namely imitation, observation, and interest in animated cartoons. With this video, students are hoped to be able to understand the material during online learning materials.

The previous research findings showed that animation media could raise the interest and motivation of students in learning (Muslina et al., 2018; Widiyasanti \& Ayriza, 2018). Animated media can improve learning results for students as well (Eli \& Sari, 2018; Iqbal \& Tarigan, 2019). Animated media can be used on math material (Awalia et al., 2019; Stoll et al., 2021). The animated video "Hands Move" helps teachers deliver material in social studies subjects (Permatasari et al., 2019; Wouters et al., 2019). Various previous research findings relating to animated video learning media but no science lessons with the material of the human digestive system have been applied. Besides, the human digestive system material has no animation media at school. This media has the advantage of giving the students an increasing interest in animation, sound, and pictures presented in a simple way, allowing the students to understand the content more easily (Chang et al., 2020; Indriyani \& Putra, 2018). This study aimed to develop animated video learning media on human digestive system material for $5^{\text {th }}$-grade students at the $2^{\text {nd }}$ Kubu Public Elementary School. Animated media of the human digestive system can help students understand the material during online learning. The media is hoped to promote and increase students' interest and motivation to learn to improve their learning outcomes.

\section{METHOD}

The type of this research is development research. The ADDIE model, which contains the following steps; Analyze, Design, Development, Implementation, and Evaluation, is the model used to refer to learning media development research. This model is selected because the model is very understandable, has a systemic flow, and is very clear. Some subjects conducted the study; two material experts, two media and design specialists, and two practitioners. The technique used in collecting data in this study is a questionnaire using the Likert scale instrument. Tables 1,2 , and 3 show the grid of data collection instruments to measure the validity of the developed learning media.

Table 1. Media Validation Sheet Grid for Animated Media Expert

\begin{tabular}{cclcc}
\hline No. & Aspect & \multicolumn{1}{c}{ Indicator } & $\begin{array}{c}\text { Total } \\
\text { Item }\end{array}$ & $\begin{array}{c}\text { Item } \\
\text { Number }\end{array}$ \\
\hline \multirow{2}{*}{1} & \multirow{2}{*}{ Content } & $\begin{array}{l}\text { The presented material suitability with the core competencies } \\
\text { and the basic competencies. } \\
\text { The material suitability with the learning video media and }\end{array}$ & 1 & 1 \\
& & The & 1 & 2
\end{tabular}




\begin{tabular}{|c|c|c|c|c|}
\hline No. & Aspect & Indicator & $\begin{array}{l}\text { Total } \\
\text { Item }\end{array}$ & $\begin{array}{c}\text { Item } \\
\text { Number }\end{array}$ \\
\hline \multirow{10}{*}{2} & \multirow{10}{*}{ Language } & indicators. & & \\
\hline & & $\begin{array}{l}\text { The material/information completeness is contained in the } \\
\text { learning video media. }\end{array}$ & 1 & 3 \\
\hline & & $\begin{array}{l}\text { The conformity between the content of the exercise and the } \\
\text { learning objectives. }\end{array}$ & 1 & 4 \\
\hline & & $\begin{array}{l}\text { The conformity between the content of the summary and the } \\
\text { core points of the learning content. }\end{array}$ & 1 & 5 \\
\hline & & $\begin{array}{l}\text { The content of the material in the learning video media arouses } \\
\text { students' curiosity. }\end{array}$ & 1 & 6 \\
\hline & & The material suitability with the example in everyday life. & 1 & 7 \\
\hline & & The language used is easy to understand. & 1 & 8 \\
\hline & & The standard language used. & 1 & 9 \\
\hline & & The effectiveness of the sentences used. & 1 & 10 \\
\hline & & The use of words following the correct spelling. & 1 & 11 \\
\hline 3 & Practical & The ease of learning video media used. & 1 & 12 \\
\hline 4 & Effective & The effectiveness of using learning video media. & 1 & 13 \\
\hline
\end{tabular}

Table 2. Animated Media Validation Sheet Grid for Material Expert

\begin{tabular}{|c|c|c|c|c|}
\hline No. & Aspect & Indicator & $\begin{array}{l}\text { Total } \\
\text { Item }\end{array}$ & $\begin{array}{c}\text { Item } \\
\text { Number }\end{array}$ \\
\hline \multirow{4}{*}{1} & \multirow{4}{*}{ Cover } & Learning Media Identity & 1 & 1 \\
\hline & & The cover attractiveness & 1 & 2 \\
\hline & & The attractiveness of learning media display & 1 & 3 \\
\hline & & $\begin{array}{l}\text { The color, writing, and pictures/videos harmony on learning } \\
\text { video media }\end{array}$ & 1 & 4 \\
\hline \multirow{4}{*}{2} & \multirow{4}{*}{ Format } & The compatibility of use and font size & 1 & 5 \\
\hline & & The suitability of the learning video media layout & 1 & 6 \\
\hline & & The suitability of the image with the material content & 1 & 7 \\
\hline & & $\begin{array}{l}\text { The stipulations of paragraph stylists describing learning } \\
\text { materials }\end{array}$ & 1 & 8 \\
\hline 3 & Practical & The ease of learning video media used & 1 & 9 \\
\hline 4 & Effective & The effectiveness in using learning video media & 1 & 10 \\
\hline
\end{tabular}

If the content validity requirements are met, an instrument can be said to be good. The instruments that have been compiled are then tested for content validity by several experts (judges) so that they can be said to be valid. The validity of the instruments was tested using the Gregory formula. Based on the content validity criteria, the content validity coefficients of the three instruments are at very high content validity criteria. Data analysis methods and techniques used in this development research use qualitative descriptive statistics and quantitative descriptive statistics. Qualitative descriptive statistical analysis is used in processing the results of reviews, suggestions, or inputs made by experts or judges on the developed learning media. Quantitative descriptive statistical analysis is used to process data as numbers from the assessment provision sheets for learning media instruments developed by media experts, design experts, science content experts, and teachers. A five-scale conversion benchmark is used to make decisions about media development.

\section{RESULT AND DISCUSSION}

\section{Result}

The animation learning media development design for the human digestive system material has been carried out with the development model named the ADDIE development model, including the Analyze, Design, Development, Implementation, and Evaluation stages. The first step is analyzing. At this stage, an analysis of needs, curriculum, and media is carried out. Based on the observations and interviews results, it was found that the learning resources used by students were limited to textbooks and worksheets and the use of media was still rarely found so that the material obtained is not optimal. The science competence knowledge of fifth-grade students of the $2^{\text {nd }}$ Kubu Public Elementary School is still low. Students tend to be bored by monotonous learning as they are not very enthusiastic about learning. 
Based on the learning media analysis results, the availability of learning media remained lacking; the current media were limited to image media only. Lack of teacher creativity to develop learning media according to student characteristics. Therefore, the teacher uses books only as a learning resource in the learning process. Curriculum analysis is done by first analyzing the basic competencies, the core competencies, indicators of competency achievement, learning objectives, and material contained in the book as a basis in the preparation of learning media developed. The results of the competency and indicators analysis are presented in Table 3.

Table 3. Basic Competencies (KD) and Competency Achievement IndicatorsTable

\begin{tabular}{cclcl}
\hline No & \multicolumn{1}{c}{ Basic Competency (KD) } & \multicolumn{2}{c}{ Competency Achievement Indicators } \\
\hline 1 & 1.1 & $\begin{array}{l}\text { Analyzing the digestive organs and } \\
\text { their functions in animals and humans } \\
\text { as well as maintaining the health of } \\
\text { human digestive organs }\end{array}$ & $\begin{array}{l}\text { Explain the meaning of the human } \\
\text { digestive system. }\end{array}$ \\
& & $\begin{array}{l}\text { Explain the process of the digestive system } \\
\text { occurrence. }\end{array}$ \\
\hline
\end{tabular}

The second stage is designing. This stage begins with the compilation of media assessment instruments and the animation learning media development design. The designed media is an animated learning video that discusses the human digestive system material. This learning media is intended for fifth-grade elementary school students. The storyboard in the developed animated video contains the stages of the plot, namely the cover, the learning video title, the video maker name, essential competencies, achievement indicators and learning video competencies, animation-based learning video storylines. Furthermore, the design of the media concept is made in the form of a storyboard. The storyboard is made to visually display animated learning media on the material of the human digestive system.

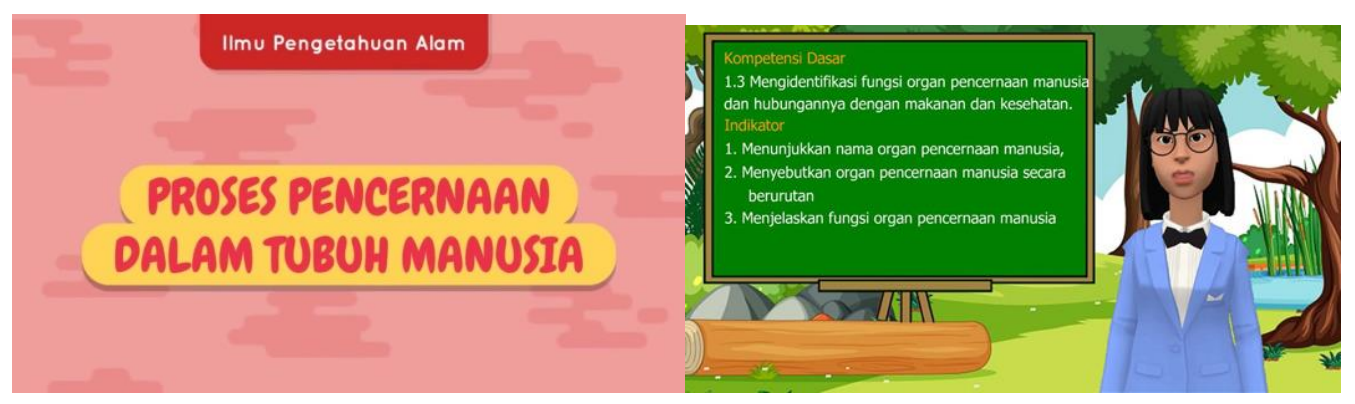

Figure 1. Design of Animation Learning Media

The actual product is being developed in this development stage. In addition, the validity of the developed animation learning media is determined by experts and practitioners on this product and to receive suggestions and comments to make improvements to the media to become appropriate learning media to use in the learning process. The calculation result of the average validity test score showed that the percentage obtained in terms of the material as a whole is $95.71 \%$. There are decent qualifications for the percentage of learning material experts from the 90-100 range, and they need not be revised. The calculation result of the validity test percentage in terms of the overall design is $94.61 \%$. The percentage result of learning design experts with outstanding qualifications ranges between 90 and 100 and need not be revised. Based on the average media expert score, it was noted that the learning media have outstanding qualifications at $92.93 \%$. Meanwhile, the practitioner test showed that the learning media had an excellent qualification with an overall percentage of $100 \%$. Based on these results, animation learning media for digestive system material in science subjects is declared valid with outstanding qualifications. After the product is completed and declared feasible, the next stage is implementing the animated video. Then, the evaluation stage is completed after the implementation stage. Due to unfavorable circumstances in the Covid-19-pandemic situation, the implementation and evaluation of this animated video of the human digestive system material could not be done. The suggestions given by experts and individual trials are presented in the Table 4. 
Table 4. Feedback and Suggestions from Experts

\begin{tabular}{|c|c|}
\hline Video Trial Subject & Feedback and Suggestions \\
\hline $\begin{array}{l}\text { Learning Material } \\
\text { Expert Test }\end{array}$ & $\begin{array}{l}\text { Learning objectives use the ABCD format; When discussing what gastric } \\
\text { juice consists of, it does not fit the video display and the text with the } \\
\text { words of explanation; The description of the pancreas does not match } \\
\text { the picture. On the slides are written amylase, trypsin, and lipase } \\
\text { enzymes; The small intestine mentioned should be the same as the } \\
\text { picture in the video; In the video, there is no evaluation according to the } \\
\text { instrument sheet. An evaluation instrument can be added at the end } \\
\text { after the conclusion. }\end{array}$ \\
\hline $\begin{array}{l}\text { Learning Design } \\
\text { Expert Test }\end{array}$ & $\begin{array}{l}\text { Learning objectives need to use the ABCD format; Use plain fonts such } \\
\text { as Arial, Tahoma, or others for easy reading; Add the supervisor at the } \\
\text { end of the video; The small intestine mentioned should be the same as } \\
\text { the picture in the video; In general, the videos made are excellent and } \\
\text { ready to be used in the learning process. Then it can be developed on } \\
\text { other themes to be more varied. In addition, examples of more } \\
\text { contextual activities can also be added. }\end{array}$ \\
\hline $\begin{array}{l}\text { Learning Media } \\
\text { Expert Test }\end{array}$ & $\begin{array}{l}\text { In the beginning, add the class, semester along with the name of the } \\
\text { developer; Show and focus the part of the respiratory apparatus in } \\
\text { question with the arrow. The videos produced are generally } \\
\text { outstanding and ready for use in the learning process. It can then be } \\
\text { more varied on other topics. Furthermore, examples can be added of } \\
\text { more contextual activities. }\end{array}$ \\
\hline $\begin{array}{c}\text { Expert Practitioner } \\
\text { Test }\end{array}$ & $\begin{array}{l}\text { Animated videos are suitable for use in elementary school; The } \\
\text { animated videos tested are good, and hopefully, there will be videos like } \\
\text { this again in other themes. }\end{array}$ \\
\hline
\end{tabular}

Based on the feedback and suggestions provided by experts and test practitioners, the developed product was then revised to a higher quality. The results of the revisions made are presented in Figure 2.

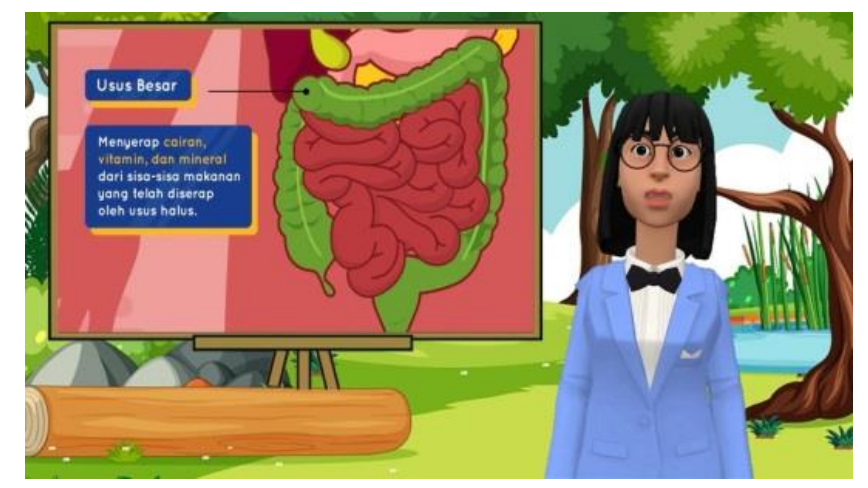

Figure 2. Revision Result of Animated Video Media

\section{Discussion}

Based on the analysis result, the animated video media of science learning, particularly the material for the human digestive system, get outstanding qualifications, so it is feasible to be applied in the learning process. It is worth developing animated video media in science learning for the human digestive system material, as this video learning medium can help students learn independently. Furthermore, this media will also facilitate learners' understanding of the learning material to influence students' learning outcomes. Animated video media for the human digestive system material in science learning has outstanding qualifications and merit application due to numerous factors. First, the developed animated video media can help students understand the material. It attracts students' attention and motivates students that can be seen from presenting the material. The developed media creatively display learning materials based on student characteristics to increase student focus (Knoop-van Campen et al., 2020; Wuryanti, 2016). Furthermore, the aspects are very credible to increase the understanding of the material by the students. It is in line with the theory that learning media are everything used to channel senders' and recipients' messages to encourage students' thoughts, concerns, feelings, and interests 
(Andriyani \& Suniasih, 2021; Indahini et al., 2018). The learning results are influenced by numerous factors, including media use in teaching and learning activities (Ilmawan Mustaqim, 2017).

Second, developed animated video media can enhance students' learning experiences. Videos enable students to increase their interest in learning because this learning media can provide a fun and efficient learning experience. Other research findings indicate that children learn more from the educational process involving media and image, color, and motion components (Najib, 2016; Rose et al., 2016; Wuryanti, 2016). Various components allow the developed media to attract interest in learning and bring students more significant learning experiences. The results of previous research on animated learning videos can be used for learning because they can increase the excitement and motivation of students in the learning process (Widiyasanti \& Ayriza, 2018). Animated video learning media is suitable for use in the learning process in elementary schools (Panjaitan, 2020; Wuryanti, 2016). Animated video media can also increase the interest and motivation of students in their Education (Hua et al., 2020; Permatasari et al., 2019; Stoll et al., 2021).

The animated video media that has been developed includes the cartoon images, sounds, words, and music presented together so that students will be more interested in learning (Chang et al., 2020; Sudiarta \& Sandra, 2016; Yuniarni et al., 2020). It can be concluded that learning media in animated videos can help students learn to help improve student learning outcomes. The benefits of this video media are attractive and highly suitable for elementary school students' characters. Moreover, the presence of photos and audio can appeal to students, so they do not have to be bored. This animated video media can be used without using an application, making it easier for students to use video media. This video media, however, develops only on one subject: human digestive system material. Moreover, the media is only developed until the validation stage. The implementation and evaluation stage cannot be carried out due to the Covid-19 pandemic. Further research at the implementation and evaluation stages is hoped to be carried out. Teachers and students can be helpful with animated video media, particularly on the human digestive system material. It is expected that the implications of this research will impact the results of student science learning.

\section{CONCLUSION}

In the scientific learning process, animated video learning media for the human digestive system material is feasible. This animated video media can help students understand science subjects, especially about human digestive system material. It is hoped that video media learning will be more efficient and effective in achieving learning goals in the learning process.

\section{REFERENCES}

Agung, A. A. G. (2014). Metodologi Penelitian Pendidikan. Deepublish.

Anugerah, S., Ulfa, S., \& Husna, A. (2020). Pengembangan Video Pembelajaran Bahasa Isyarat Indonesia (Bisindo) untuk Siswa Tunarungu di Sekolah Dasar. JINOTEP (Jurnal Inovasi dan Teknologi Pembelajaran): Kajian dan Riset dalam Teknologi Pembelajaran, 7(2), 76-85. https://doi.org/10.17977/um031v7i22020p076.

Batubara, H. H., \& Batubara, D. S. (2020). Penggunaan Video Tutorial untuk Mendukung Pembelajaran Daring di Masa Pandemi Virus Corona. Muallimuna: Jurnal Madrasah Ibtidaiyah, 5(2), 21. https://doi.org/10.31602/muallimuna.v5i2.2950.

Bujuri, D. A. (2018). Analisis Perkembangan Kognitif Anak Usia Dasar dan Implikasinya dalam Kegiatan Belajar Mengajar. LITERASI (Jurnal Ilmu Pendidikan), 9(1), 37. https: //doi.org/10.21927/literasi.2018.9(1).37-50.

Chang, T., Hsu, M., Kwon, J., Kusdhadny, M. L. S., \& Hong, G. (2021). Effect of Online Learning for Dental Education in Asia During the Pandemic of COVID-19. Journal of Dental Sciences. https: //doi.org/10.1016/j.jds.2021.06.006.

Che Mat, A., Awang, A., Zulfadhli Nokman, A., Musilehat, N., \& Fakrulazizi Abu Bakar, A. (2017). An Authentic Learning Environment Based on Video Project among Arabic Learners. International Journal of Applied Linguistics and English Literature, 6(4), 143. https://doi.org/10.7575/aiac.ijalel.v.6n.4p.143.

Cheppy, R. (2017). Pedoman Pengembangan Media Video. P3AI UPI.

Chorianopoulos, K. (2018). International Review of Research in Open and Distributed Learning. International Review of Research in Open and Distributed Learning, 32(3), 83-93. 
Damayanthi, A. (2020). Efektivitas Pembelajaran Daring di Masa Pandemi Covid 19 pada Perguruan Tinggi Keagamaan Katolik. Edutech: Jurnl Teknologi Pendidikan, 19(3), 189-210. https://doi.org/10.17509/e.v1i3.26978.

Darmawati, J. (2017). Pengaruh Motivasi Belajar dan Gaya Belajar terhadap Prestasi Belajar Ekonomi Siswa SMA Negeri di Kota Tuban. Jurnal Ekonomi Pendidikan dan Kewirausahaan, 1(1), 79. https://doi.org/10.26740/jepk.v1n1.p79-90.

Ekayani, P. (2017). (2017). Pentingnya Penggunaan Media. Jurnal Fakultas Ilmu Pendidikan Universitas $\begin{array}{llll}\text { Pendidikan Ganesha } & \text { Singaraja, } & \text { 2(1), }\end{array}$ https://www.researchgate.net/publication/315105651.

Fiorella, L., \& Mayer, R. E. (2018). What Works and Doesn't Work with Instructional Video. Computers in Human Behavior, 89, 465-470. https://doi.org/10.1016/j.chb.2018.07.015.

Fitriyah, D. (2021). Pengembangan Video Tutorial Praktikum Kimia Umum Berbasis Kehidupan Seharihari di Masa Covid-19 ( Studi Kasus Pendidikan Kimia Universitas Maritim Raja Ali Haji Tanjungpinang ). Journal of Education and Teaching, 2(1), 63-69.

Fitriyani, Y., Fauzi, I., \& Sari, M. Z. (2020). Motivasi Belajar Mahasiswa pada Pembelajaran Daring selama Pandemi Covid-19. Profesi Pendidikan Dasar, 7(1), 121-132. https://doi.org/10.23917/ppd.v7i1.10973.

Gazali, Z., \& Nahdatain, H. (2019). Pengembangan Media Pembelajaran Berbasis Video pada Materi Biologi Sel untuk Siswa SMA/MA Kelas XI IPA. JUPE: Jurnal Pendidikan Mandala, 4(5), 236-238. https://doi.org/10.36312/jupe.v4i5.867.

Handarini, O. I., \& Wulandari, S. S. (2020). Daring to Draw Causal Claims from Non-Randomized Studies of Primary Care Interventions. Jurnal Pendidikan Administrasi Perkantoran (JPAP), 8(3), 496-503. https://journal.unesa.ac.id/index.php/jpap/article/view/8503.

Herliandry, L. D., Nurhasanah, N., Suban, M. E., \& Kuswanto, H. (2020). Pembelajaran pada Masa Pandemi

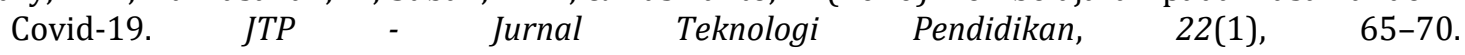
https://doi.org/10.21009/jtp.v22i1.15286.

Hidayati, A., Adi, E., \& Praherdhiono, H. (2019). Pengembangan Media Video Pembelajaran untuk Meningkatkan Pemahaman Materi Gaya Kelas IV di SDN Sukoiber 1 Jombang. JINOTEP Uurnal Inovasi dan Teknologi Pembelajaran) Kajian dan Riset dalam Teknologi Pembelajaran, 6(1), 45-50. https://doi.org/10.17977/um031v6i12019p045.

Hisbullah, \& Selvi, N. (2018). Pembelajaran Ilme Pengetahuan Alam di Sekolah Dasar. Akasa TIMUR.

Ilham, D. (2019). Menggagas Pendidikan Nilai dalam Sistem Pendidikan Nasional. 8(3), 109-122.

Lestari, N., \& Wirasty, R. (2019). Pemanfaatan Multimedia dalam Media Pembelajaran Interaktif untuk Meningkatkan Minat Belajar Siswa. Amaliah: Jurnal Pengabdian kepada Masyarakat, 3(2), 349353. https://doi.org/10.32696/ajpkm.v3i2.289.

Mayer, R. E., Fiorella, L., \& Stull, A. (2020). Five Ways to Increase the Effectiveness of Instructional Video. Educational Technology Research and Development, 68(3), 837-852. https://doi.org/10.1007/s11423-020-09749-6.

Munirah,Alim Bahri, F. (2019). Pengaruh Penggunaan Media Gambar Seri terhadap Keterampilan Menulis Cerita Dongeng Siswa Kelas III SD. Jurnal Kajian Pendidikan Dasar, 4(2), 731-740.

Mutia, R., Adlim, A., \& Halim, A. (2018). Pengembangan Video Pembelajaran IPA pada Materi Pencemaran dan Kerusakan Lingkungan. Jurnal Pendidikan Sains Indonesia, 5(2), 110-116. https://doi.org/10.24815/jpsi.v5i2.9825.

Novita, L., Sukmanasa, E., \& Pratama, M. Y. (2019). Penggunaan Media Pembelajaran Video terhadap Hasil Belajar Siswa SD. Indonesian Journal of Primary Education Penggunaan, 3(2), 64-72. http://ejournal.upi.edu/index.php/IJPE/index.

Nurdin, E., Ma'aruf, A., Amir, Z., Risnawati, R., Noviarni, N., \& Azmi, M. P. (2019). Pemanfaatan Video Pembelajaran Berbasis Geogebra untuk Meningkatkan Kemampuan Pemahaman Konsep Matematis Siswa SMK. Jurnal Riset Pendidikan Matematika, 6(1), 87-98. https://doi.org/10.21831/jrpm.v6i1.18421.

Pawicara, R., \& Conilie, M. (2020). Analisis Pembelajaran Daring terhadap Kejenuhan Belajar Mahasiswa Tadris Biologi Iain Jember di Tengah Pandemi Covid-19. ALVEOLI: Jurnal Pendidikan Biologi, 1(1), 29-38.

Pratama, R. E., \& Mulyati, S. (2020). Pembelajaran Daring dan Luring pada Masa Pandemi Covid-19. Gagasan Pendidikan Indonesia, 1(2), 49. https://doi.org/10.30870/gpi.v1i2.9405.

Rossalyna, E. (2017). Pembuatan Video Panduan Layanan Perpustakaan. Ilmu Informasi Perpustakaan dan Kearsipan, 6(1), 105-108.

Sadikin, A., \& Hamidah, A. (2020). Pembelajaran Daring di Tengah Wabah Covid-19. Biodik, 6(2), 109-119. https://doi.org/10.22437/bio.v6i2.9759. 
Safitri, E. N., \& Zafi, A. A. (2020). Konsep Humanisme Ditinjau dari Perspektif Pendidikan Islam. $A L-$ Murabbi: Jurnal Studi Kependidikan dan Keislaman, 7(1), 78-89. http://ejournal.kopertais4.or.id/mataraman/index.php/murabbi/article/view/3842.

Septiani, M. T. (2019). Media Audio Visual untuk Pembelajaran Musikalisasi Puisi. BASINDO : jurnal Kajian Bahasa, Sastra Indonesia, dan Pembelajarannya, 3(1), 31-37. https://doi.org/10.17977/um007v3i12019p031.

Setiawan, B., Pramulia, P., Kusmanarti, D., Juniarso, T., \& Wardani, I. S. (2021). Peningkatan Kompetensi Guru Sekolah Dasar dalam Pengembangan Bahan Ajar Daring di SDN Margorejo I Kota Surabaya. Manggali: Jurnal Pengabdian dan Pembelajaran Masyarakat, 1(1), 46-57. https://doi.org/10.31331/manggali.v1i1.1547.

Sholihin, M., Sari, R. C., Yuniarti, N., \& Ilyana, S. (2020). A New Way of Teaching Business Ethics: The Evaluation of Virtual Reality-Based Learning Media. International Journal of Management Education, 18(3), 100428. https://doi.org/10.1016/j.ijme.2020.100428.

Sulfemi, W. B. (2018). Penggunaan Metode Demontrasi dan Media Audio Visual dalam Meningkatkan Hasil Belajar Peserta Didik Mata Pelajaran IPS. Pendas Mahakam: Jurnal Pendidikan Dasar, 3(2), 151158. https://doi.org/10.31227/osf.io/qrhsf.

Supriyono. (2018). Pentingnya Media Pembelajaran untuk Meningkatkan Minat Belajar Siswa SD. Edustream: Jurnal Pendidikan $\quad$ Dasar, https://journal.unesa.ac.id/index.php/jpd/article/view/6262/3180.

Suriyanti, Y., \& Thoharudin, M. (2019). Pemanfaatan Media Pembelajaran IPS untuk Meningkatkan Keterampilan Guru IPS Terpadu. JPPM (Jurnal Pengabdian dan Pemberdayaan Masyarakat), 3(1), 117. https://doi.org/10.30595/jppm.v3i1.3507.

Syahputra, A., \& Maulida, R. (2019). Perancangan Media Pembelajaran Fisika Berbasis Multimedia (Studi Kasus : SMK TI Swasta Budi Agung Medan). Jurnal Teknik Informatika Kaputama, 3(1), 15-21.

Syamsuddin, A., \& Lukman, A. (2019). Penggunaan Media Edukasi Hitung Kompak dan Dampaknya terhadap Kemampuan Berhitung Siswa Sekolah Dasar. JRPD (Jurnal Riset Pendidikan Dasar), 2(1), 1-8. https://doi.org/10.26618/jrpd.v2i1.2052.

Tegeh, I. M., \& Kirana, I. M. (2010). Metode Penelitian Pengembangan Pendidikan. Universitas Pendidikan Ganesha.

Tegeh, I. M., Simamora, A. H., \& Dwipayana, K. (2019). Pengembangan Media Video Pembelajaran dengan Model Pengembangan 4D pada Mata Pelajaran Agama Hindu. Mimbar Ilmu, 24(2), 158. https: //doi.org/10.23887/mi.v24i2.21262.

Ulyana, A., Abidin, Z., \& Husna, A. (2019). Pengembangan Video Pembelajaran Kalor untuk Siswa Kelas VII. JINOTEP OUrnal Inovasi Teknologi Pembelajaran), http://dx.doi.org/10.17977/um031v5i22019p081.

Yanto, D. T. P. (2019). Praktikalitas Media Pembelajaran Interaktif pada Proses Pembelajaran Rangkaian Listrik. INVOTEK: Jurnal Inovasi Vokasional dan Teknologi, 19(1), 75-82. https://doi.org/10.24036/invotek.v19i1.409.

Yuanta, F. (2020). Pengembangan Media Video Pembelajaran Ilmu Pengetahuan Sosial pada Siswa Sekolah Dasar. Trapsila: Jurnal Pendidikan Dasar, 1(02), 91. https://doi.org/10.30742/tpd.v1i02.816. 